\title{
Bombast Bombardment and Dense Syntax versus Effective Communication and Language Teaching in ESL Settings: Nigerian English Examples
}

\section{Bombardeo rimbombante y sintaxis densa versus comunicación efectiva y enseñanza de idiomas en entornos de ESL: ejemplos del inglés nigeriano}

\author{
Omowumi Olabode Steven Ekundayo'
}

Citation/ Para citar este Artículo: Ekundayo, B. S. (2021). Bombast Bombardment and Dense Syntax versus Effective Communication and Language Teaching in ESL Settings: Nigerian English Examples. Colomb. Appl. Linguistic. J., 23(2), pp. 229-242.

Received: 17-Apr.-2020 / Accepted: 15-Jul.-2021

DOI: https://doi.org/10.14483/22487085.16161

\begin{abstract}
Influenced by certain factors and motives, some educated Nigerian English speakers use high-sounding expressions, as well as dense, windy, and complex syntactic structures. This paper examines this linguistic habit in Nigerian English to show how entrenched it has become; explain the sociolinguistic, historical, and idiosyncratic factors that influence it; show its effect on its audience and readers; and determine its implications for teaching and learning English in English as a second language (ESL) settings. The paper adopted the qualitative research method, and data were extracted from both primary and secondary sources. Primary data were extracted from well-known Nigerian 'bombast bombardiers' (users of bombast). Secondary data were gleaned from historical events and published and creative works. The study established that the use of 'language explosives' (high-sounding lexical items) is a common linguistic habit in ESL. Some educated Nigerians, for instance, use the habit to show off learning and their mastery of the language, estrange others in communication, create humor, and gain popularity. Although the paper avers that the habit in its unguided form hampers effective communication, it submits that it possesses certain socio-political and pedagogical utilities in ESL settings.
\end{abstract}

Keywords: Nigerian English, bombast bombardiers, language teaching, dense syntax, English as a second language

\section{Resumen}

Influenciados por ciertos factores y motivos, algunos nigerianos educados hablantes de inglés utilizan expresiones altisonantes, así como estructuras sintácticas densas, llenas de muchas palabras (con poco significado) y complejas. Este artículo examina este hábito lingüístico en el inglés nigeriano para mostrar cuán arraigado se ha vuelto; explicar los factores sociolingüísticos, históricos e idiosincrásicos que influyen en él; mostrar su efecto en su audiencia y lectores; y determinar sus implicaciones para la enseñanza y el aprendizaje del inglés como segunda lengua (ESL). El documento adoptó el método cualitativo de investigación y los datos se extrajeron de fuentes primarias y secundarias. Los datos primarios se extrajeron de conocidos 'bombarderos grandilocuentes' (usuarios de la grandilocuencia) nigerianos. Los datos secundarios se obtuvieron de eventos históricos y trabajos publicados y creativos. El estudio estableció que el uso

1 Department of English and Literature, University of Benin, Benin City. ORCID (D): https://orcid.org/0000-0002-8846-2431. bode. ekundayo@uniben.edu, ekuns20@yahoo.com. 
de 'explosivos de lenguaje' (elementos léxicos de alto sonido) es un hábito lingüístico común en ESL. Algunos nigerianos educados, por ejemplo, usan este hábito para presumir su aprendizaje y dominio del idioma, alejar a otros en la comunicación, crear humor y ganar popularidad. Aunque el artículo afirma que el hábito en su forma no guiada obstaculiza la comunicación efectiva, sostiene que posee ciertas utilidades sociopolíticas y pedagógicas en entornos de ESL.

Palabras clave: inglés nigeriano, bombarderos grandilocuentes, enseñanza de lenguas, sintaxis densa, inglés como segunda lengua (ESL)

\section{Introduction}

Bombast, the more established term for the linguistic phenomenon hereby examined, may be likened to bomb-blast, which a speaker or writer detonates. Like a real bomb, its explosion is noisy, and it may destroy meaning and communication just as a bomb destroys lives and property. In this paper, the linguistic habit of detonating highfalutin expressions in writing and speaking is termed "bombast bombardment", and the linguistic items themselves are called "language bombs and explosives." Bombasts, inkhorn terms, blowing grammar, sesquipedalia, grandiloquence, turgidness, bombastical, etc. are other terms for bombast (Merriam-Webster, 2004; Kperogi, 2013). These terms refer to a loud style of speaking and writing replete with ostentatious sentiments and magniloquent expressions. It originated from bombyx, a Greek word for silkworm, which later became bombace, meaning a cotton wool used as padding in French (Merriam-Webster, 2004). In the 16th century, during the Middle English period, it was used figuratively to denote the use of grandiloquent words to pad writing and public speaking (Teilanyo, 2003). For example, an educated Nigerian who missed a meeting with some friends, gave the excuse below in high-sounding words:

\section{Extract 1:}

Please, pardon my ineluctable absence which must have created an unfillable hiatus in the rendezvous. The drenching diurnal pluvial decidedly overwhelmed the entire milieu with a deluge reminiscent of Noah's epoch, saturating my vulnerable self to my narrows and consequently precluding my planned locomotion to your domiciliary cocoon for our intended tête-à-tête. (Chris Ehigie's SMS text from cellphone number +2348132549659 to +2348037243494 on 4th August, 2019)

The word "rendezvous" is pronounced / rendezvos/ and the last word as /tete' $\alpha$ tetc/. This linguistic habit, entrenched in Nigerian English, finds loud expression in formal writing, public speaking, literary works, politics, and legal drafting. However, much research attention has not been paid to the entrenched habit besides Ubahakwe's (1974) study of bookish English in Nigeria, Teilanyo's (2003) similar paper on the use of bombast in two electronic media plays in non-standard Nigerian English, and some cursory comments on the habit in social media and in two recently published works (Kperogi, 2013, 2015). The frontiers of these works and comments ought to be expanded and updated with further studies on this habit and people's attitude towards it. Bombast is a common language habit among users of New Englishes, which has some implications for effective communication and language teaching and learning in ESL settings with specific reference to Educated Nigerian English (ENE).

ENE is used here in the sense of Banjo's variety III of Nigerian English (Banjo, 1971, 1996), as well as according to Ekundayo (2014), which are cited in the literature review section of this paper. Although the habit is prevalent in Nigerian English (NigE), studies on the historical, sociolinguistic, psycholinguistic, and attitudinal factors that inform and influence it are scanty. Yet, the habit has implications for social interaction, communication, and language teaching, which Nigerian linguists and grammarians ought to mind, investigate, and describe in order to facilitate effective communication, socio-political interaction, and language teaching and learning. Considering the above, this paper aims to examines some idiolects by some educated Nigerian users of bombast to answer the following questions:

I. What is the nature and structure of bombast in English? 
II. How do readers and audience of linguistic explosives often feel about and react to them?

III. What are its implications for effective communication and teaching effective communication and vocabulary development in ESL?

Subsequent sections of the paper present the methodology, conceptual issues, literature review, presentation and discussion of data, implications for teaching and learning, and conclusions.

\section{Methodology}

This is a basic study, a qualitative sociolinguistic textual analysis of a variety of ENE called Blowing Grammar, the habit of using grandiloquent verbiage. The paper adopted the record-keeping qualitative method of research, which involves the reading and analyses of reliable library materials (Radu, 2019; Schreier et al., 2016). The universe of the study is Nigeria and educated Nigerians. Data were assembled from three main sources. The first group of examples were taken from socio-historical materials. These include examples from the addresses of Nigerian nationalists such as Nnamdi Azikiwe, Adelabu Adegoke, Mbonu Ojike, and K. O. Mbadiwe. The second group of examples was drawn from the characters and language of the literary works of Wole Soyinka's The Lion and the Jewel (1963), The Man Died (1972), The Interpreters (1975); Jonathan Ihonde's Hotel de Jordan television drama series (1973 to 2000); and the Professor Johnbull television drama series (2016-2018). The sources of the third group are well-known bombast bombardiers in Nigeria, who include Wole Soyinka, Adebayo Williams, Rev. Chris Okotie, Uthman Shodipe, Patrick Obahiagbon, the Ogodomigodo of Africa, and Fadda the Grammarian.

Bombastic features were purposively sampled from the writings, dialogues, and addresses of the aforementioned literary characters and real life personalities to establish their prevalence in ENE. In addition to using selected language performances of the aforementioned bombast bombardiers, Patrick Obahiagbon, the most famous among them, and
Marxist Kola Edokpayi, were interviewed to ascertain why they use bombast and what they have gained from the habit.

The data presentation method is textual: data were presented as linguistic texts in serial and chronological order, as well as analysed and explained to show bombastic features and dense and windy structures. The samples used were numbered consecutively as "Extract" from 1 to 22 . The syntactic analysis was based on the simplified pattern of sentence analysis by Quirk et al. (1985), as presented in section 3 . Bold vertical strokes ( |, |, I) were used to demarcate major sentence slots and grammatical structures such as subject, verb, object, complement and adverbial while slanted strokes (/, /, /) were used to mark structures premodifying or complementing the major sentence grammatical items and functions. The implications and causes of blowing grammar were also explained using insights from the conducted interviews and the observation and experience of the researcher as a teacher and public speaker in Nigeria.

\section{Conceptual issues and literature review}

The paper is based on the concepts of blowing grammar, Nigerian English, and sociolinguistics. The syntactic analysis is informed by Quirk, et al's (1985) method of syntactic analysis. The idiom to blow grammar has become institutionalized in Nigerian English and is, perhaps, peculiar to Nigerian English. The idiom itself emanated from a sense of grammar in NigE. Apart from its general standardised meaning, grammar has an extended figurative meaning in NigE, which refers to the use of windy, dense structures of syntax and grandiloquent verbiage. Therefore, to blow grammar in NigE means to use magniloquent words and cacophonous expressions that may or may not make sense to a reader or listener. When Nigerians say that one is blowing grammar, they mean that one is using grandiloquent expressions, or one is not making sense.

One of the earliest works on blowing grammar in Nigerian English is Ubahakwe's (1974) study of 
bookish English among Nigerian students, in which he established that Nigerian students use very formal and loud expressions in their spoken English as a result of the fact that they learned English in formal settings such as classroom teaching and the reading of sundry literature and Englishteaching texts. Kperogi (2013) says that many Nigerian users of English "use the term 'grammar' to mean pretentious unfamiliar words" (p.1). For instance, if a speaker or writer were to use words like "tintinnabulation," "propinquity" "concatenation," etc., Nigerian English speakers would describe them as "blowing grammar". But that is a nonstandard meaning of "grammar." Kperogi (2013) argues that the use of grammar in this sense is wrong or an error: "There is a category of usage errors in Nigerian English that I like to call bad grammar about grammar. By this I mean our tendency to misuse and encipher the terminologies of grammarians with our unique meanings" (p.1). He says that grammar by standardized usage "means the branch of linguistics that is concerned with syntax (arrangement of words in sentences), morphology (rules for forming words) and, sometimes, semantics (study of meaning). In other words, grammar basically means the science of correct usage of a language" (p.1).

While this standardized meaning of grammar, as Kperogi (2013) presents it, is correct, it is pedantic to say that the idiom "to blow grammar" and the extra sense of the word "grammar" in NigE is wrong because the fabrication has not violated any rule of grammar that Kperogi himself defines. The only question about it is that it is not in Standard British English (SBE) and other national English varieties. The fact that a word or idiom in an English variety is not in SBE does not make the expression an error. The term is a product of semantic extension, and we should also recall that, through semantic extension, grammar has many meanings, even in standardized and pedagogical usage. Although the linguistic habit of using big and loud words may be termed "inkhorn terms," "sesquipedalia," "bombast", etc., in NigE, it is widely and acceptably tagged "blowing grammar" or simply "grammar"; for example, "you are just blowing grammar", which means "you are using high-sounding words that I don't understand", "you are not making sense", or "even though you seem to be making sense, I disagree with you."
Elsewhere, Kperogi (2018) shows that "Nigerian English is filled with words that are either exclusively invented by Nigerian English speakers or retained from long forgotten archaic British English" (p. 1). The use of such coinages and archaisms make the idiolects of some NigE users either bombastic or old-fashioned, bookish or pedantic. Some examples are "trafficate," "detribalize," "confutionist," "instalmentally," "jealousing," "cattle rearer," etc., which he categorizes as errors obviously because they are not used in standardized mother tongue and firstlanguage-setting English, e.g. British and American varieties. However, a critical look at the words will show that educated Nigerian speakers redeployed English word-formation processes and retained some archaic English words, a linguistic habit that Ekundayo (2014) conceptualizes as morphological intraference. Previous scholars and commentators assert that the habit of bombast bombardment is widespread in Africa and Nigeria from colonial to contemporary times. Nationalists, writers, politicians, orators, preachers, classroom teachers, and students have deliberately cultivated the habit of acquiring a nest of huge and cacophonous words, which they shower in speaking and writing to achieve an end (Mazrui, 2019; Adeniran, 1979; Jowitt, 1991; Banjo, 1996; Teilanyo, 2003).

Teilanyo (2003) assessed the use of bombast in Nigeria, drawing examples from the creative idiolectal English of two main characters in two mass-media comedies entitled Icheoku, and the Masquerade. He identified the general elements and "the expressive and perceptive dimensions of bombast" (p.77), as well as its motives and effects on its target audience. He concluded that the use of bombast shows that the speakers are ignorant of or indifferent to "the essential communicative function of language, and the powerful status symbol that English language users obtain in African English-as-second-language (ESL) societies" (pp. 77, 100). Teilanyo's (2003) work on bombast is similar and identical to this study in several parts. The objectives, scope, conceptual thrust, and methodology are similar and, in some parts, the data were drawn from the same sources such as Soyinka's The Lion and the Jewel and Patrick Obahiagbon. However, Obahiagbon's examples in this paper are more current. While a 
bulk of Teilanyo's examples were taken from the "non-standard" idiolects of two literary characters, the examples here were taken from the idiolects of different educated Nigerians. Moreover, this paper presents the implications of bombast bombardment for language teaching and learning in ESL settings, as well as the syntactic-density analysis of some samples against the backdrop of sociolinguistics and Nigerian English.

The history and environment of educated Nigerian users of English as a second language influence the way in which they acquire and use English. Certain socio-historical, cultural, and environmental factors that characterize an ESL setting influence the use of English in Nigeria; and, as an outcome of the combination of these factors, Nigerians are constrained to (re)deploy English language rules and features in certain ways to capture and effectively express their socio-cultural personalities and intended meanings. Consequently, the Nigerian speaker produces a new variety which has come to be known and accepted as Nigerian English.

\section{Historical and sociolinguistic backgrounds}

The English language established its roots in Nigeria in the 19th century, beginning from 1862, when Lagos became a British colony, and in the 20th century, beginning from 1914, when Lord Lugard amalgamated the Lagos and Northern Protectorates to beget Nigeria in 1914, a blend of Niger or Nigger and area (Nigger-area), a derogatory term that ought to have been changed since independence in 1960. English became the official language which the colonized natives must learn. Primary schools and a few secondary schools were built to educate Nigerians in English to make them obedient civil servants and clerical officers to run the machinery of imperialism. Education, certification, and proficiency in English were sine-qua-nons for employment in the colonial civil service establishments and for effective communication with the British colonial masters, on the one hand, and the multilingual people of the new amalgam called Nigeria, on the other hand. Consequently, proficiency in English became a status symbol, as well as an imperative for expressing scholarship and facilitating social interaction (Omolewa, 1979; Akere, 2006).
By the time the nationalistic struggle reached its peak in the 1950 s, many Nigerians had become very well-educated, conscious, and courageous enough to demand self-rule from the British imperialists. David Jowitt (1991) observed that "the nationalist politicians in the 1940s and 1950s were often experienced practitioners of a highly refined English style both in speaking and writing", and that some of them fell to the lure of playing to the gallery by using "jargon and babu" (p.15), a term the British colonialists used in India to denote grandiloquent and complex expressions (p.23). Among the Nigerian nationalists were Herbert Macaulay, Nnamdi Azikiwe (who attended British-established schools in Nigeria and went to the United Kingdom and the United States of America for their higher education), Chief Obafemi Awolowo, Tafawa Balewa (the Golden Voice of Africa), Michael Okpara, Remi Fani-Kayode, Bode Thomas, Nwafor Orizu, Zana Rima Dipcharima, Mbonu Ojike, K. O. Mbadiwe, Anthony Enahoro, Adelabu Adegoke, and many others too numerous to list here.

Unavoidably, English became the linguistic weapon for the nationalist struggle, as well as the language used to mobilize the masses of Nigeria for the struggle for freedom from colonialism. Consequently, the nationalists had to learn and use the best forms of the language, which were mostly learned from standardized varieties, literary texts, classroom, and the colonialists, as they were under pressure to prove their mettle to the arrogant colonialists. They also wanted to demonstrate that they had come of age and were qualified and ready to lead their country. This mindset prepared the grounds for their use of standard and grand expressions to intimidate the colonialists, as well as to thrill the illiterate and half-educated masses. This socio-historical background combined with the sociolinguistic dynamics of the setting to make bombast bombardment a sublime feat to achieve and the hallmark of learning and scholarship.

Teilanyo (2003) identifies three causes of the linguistic habit, which are (i) "the fact that bombasters" do not know that they are not communicating, (ii) playing to the gallery, and (iii) the transfer of "the oratorical devices in traditional 
society" (p. 88) While these factors are largely responsible, the first factor is debatable because bombast bombardiers consciously denote linguistic bombs, and they are aware that their audience may not understand them, as is the case of the highly educated Nigerian samples of this study. Obahiagbon, in a brief chat with the researcher at an Art Exhibition on June 7th, 2018 in Benin City, said that he read(s) for several hours daily and loves his bombastic style, which has made him a prized public speaker and entertainer. Kola Edokpayi, a friend of the researcher, also admitted that he read the dictionary regularly and looked forward to publicly using the plethora of magniloquent words he had found and internalized.

In addition to Teilanyo's three factors is a fourth one of vocabulary wealth and aggrandizement by some Nigerians who read dictionaries like any other textbook. Educated Nigerians learn English mainly from reading and consulting dictionaries regularly, thereby amassing many words and structures. The fifth factor, which arises from the fourth, is language ostentation: the deliberate intention and desire to show off scholarship and oratory. Educated Nigerians are often minded or psychologically pressured to prove their scholarliness by blowing heavy grammar. Added to the fifth factor is the mindset of using language to confuse, douse tension, and create humor, as well as the desire to stand out and gain fame in different fields of endeavor. The fact that most bombast bombardiers are very successful people (e.g. Wole Soyinka, who won the Nobel Prize in Literature in 1986, Obahiagbon, a successful and popular politician, Chris Okotie, a wealthy and popular pastor and televangelist, etc.) equally makes more speakers and writers tread the path of blowing grammar, bombarding their audience and listeners with language explosives in politics, legal drafting, university orations, public speaking, writing, literature, and teaching. To this extent, it can be rightly asserted that the habit of bombast bombardment characterises ENE. Although not all educated Nigerians are bombast bombardiers, Nigerians tend to enjoy the habit and react to it in different ways.

Unlike speakers of English as a mother tongue who acquired their native English at home and in other informal settings, most Nigerians learn(ed) English formally at school, reading grammar books and dictionaries in a peculiar Nigerian socio-cultural background. As a result, certain socio-cultural factors were bound to render their English different from mother-tongue English or English as a first language. Language transfer, for instance, would inevitably influence their English, and they would logically use textbook English and a literary style when speaking, unlike native English speakers who naturally know how to keep the two registers of speaking and writing very clearly apart. Significantly too, a majority of the masses were stark illiterates in colonial and post-independence Nigeria. Learning English was a herculean task, but speaking and writing it competently conferred prestige and power on the fortunate users. In that kind of setting, every firmly woven structure of oratory by public speakers and writers sounded strange and bombastic in the ears of an illiterate and a bewildered audience, who, as a result, regarded the speakers as highly educated and awe-inspiring.

Nigerian English has been studied and categorised from different dimensions since the 1950s. The most typical of NigE typologies has been Banjo's varieties of Nigerian English (1996, earlier presented in 1971). Banjo categorised NigE into varieties I, II, III, and IV. Variety I is the lowest type, which primary school dropouts and leavers use. It is replete with egregious grammatical errors and broken structures. Variety II, he says, is the most popular form of Nigerian English, which is spoken by more than $70 \%$ of literate Nigerians: secondary school leavers, junior civil servants, the rank and file of the Nigerian armed forces, etc. Errors of grammar are reduced in this variety. Variety III is spoken by welleducated Nigerians: graduates, writers, teachers and lecturers, pastors, senior military officers, the judiciary, government, diplomats, among others. However, about 5\% of educated Nigerians use variety III, which is Educated Nigerian English and the variety that speakers of varieties I \& II aspire to speak. At present, in 2020, the number of speakers who use this variety is in around of $20 \%$ of the population (Adegbite, 2020).

Lastly, Banjo's variety IV is identical to Queen's English, RP, American or any other English as a 
first language or mother tongue. However, very few educated Nigerians speak this variety. It is the idiolect of few Nigerians who were born and brought up among native speakers of English in the UK and the USA or half-castes, or those Nigerians who have learned over time to imitate the phonological mannerism of native English people. Banjo says that variety IV is not widely accepted because it sounds too affected and foreign. In Nigeria today, Banjo's assertion about the social disdain for variety IV remains the reality in some quarters; for example, when its exponent is in the midst of Nigerian speakers of varieties I and II. Nevertheless, speakers of variety IV in variety III environments are often admired, but not necessarily imitated, for achieving the use of a foreign accent. Users of variety III in the main often exhibit the linguistic habit examined in this paper.

\section{Results and Discussion}

This section presents results and discusses them in line with the questions that guided the study. Accordingly, the nature and structures of bombast in NigE, selected examples from secondary materials, and the speeches of several bombast bombardiers are presented and discussed. People's reactions to bombast and its implications for teaching and learning English in second language settings are also discussed.

Nature and structure of bombasts in NigE: samples from colonial and postcolonial times

The degrees of bombast and dense grammatical structures vary from one speaker to another. Nnamdi Azikiwe's coinages and dense English structures sounded lofty to his less educated and largely illiterate audience. "Zik of Africa", as he was popularly called, and Chief Obafemi Awolowo, were polemical, analytic, and philosophical. Zik was more grandiloquent than Awolowo, and Awolowo was more deeply ideological, reflective, and prophetic in his dense composition in English. K. O. Mbadiwe was flamboyant in his dress and speech styles, as Festus Okotiebor also was. Extracts 1 and 2 below are characteristic of Zik:

\section{Extract 2: \\ S V \\ | The realisation of New Africa | can only be \\ C \\ A}

| possible | i. by the African cultivating spiritual balance, i. which leads to the practicalisation of social regeneration, ii. to realising economic determination|, iii. |becoming mentally emancipating|, and iv. ushering in a political resurgencel. (Jones, 1965, p. 116)

Although educated Nigerians today may find this specimen easy, it sounded complex to half-educated and illiterate Nigerians in colonial times. The Subject $(\mathrm{S})$, Verb (V), and the Adverbial structures (A) are complex and dense. The latter has several layers of subordinated clauses numbered with Roman figures $i$ to iv. The sentence contains some loud words that average Nigerian readers may find difficult to grasp without consulting a dictionary, such as "spiritual balance", "practicalisation of social regeneration", "mentally emancipating", and "political resurgence". The sentence is windy and complex, modified with complex phrases and clauses.

K. O. Mbadiwe was another nationalist famous for his grandiloquent language and flamboyant fashion and showmanship. He once described himself as

"a man of timber [a huge log of wood in NigE] and caliber" (Extract 3).

During the arson and vandalism in the Western Region of the early and mid-1960s in Nigeria, Mbadiwe was quoted to have used the poetic aphorism in specimen 4 below:

\section{Extract 4:}

\section{A}

|When /the come//comes/ to become/,|

S $\mathbf{V}$

S $\quad \mathrm{V} \quad \mathrm{C}$

|we | shall come out|.

As simple as this sentence sounds and appears, it is a complex syntactic formative having three major syntactic layers and slots. $\mathbf{A}$ is the adverbial slot filled by an adverbial clause introduced by the adverbial 
clause marker (complementizer) "when". The clause itself is "...the come comes to become," which is further analyzed below as svc. This is subordinated to the independent simple sentence containing the $\mathbf{S}$ (subject), and aux (auxiliary shall), as well as the phrasal verb "come out". Even though the words in example 4 above are not high-sounding, the poetic syntax and deep structure are complex. It is hard to quickly state the exact meaning of the structure. Perhaps, what he meant, given the context of the utterance, is "we will come out or react at the critical point, when it is necessary".

Odimegwu Ojukwu, the Biafran warlord, another bombast bombardier, described Mbadiwe as follows:

\section{Extract 5:}

"He was grand, his action grandiose, and his speeches grandiloquent" (Ohia, 2008).

This sentence contains three short sentences rendered compact with ellipses. The full form would be "He was grand. His action [was] grandiose, and his speeches [were] grandiloquent."

Adelabu Adegoke (1915-1958), alias "Adelabu penkelemensi" was an orator described as "the stormy petrel of Ibadan politics". In the hey days of violence and confusion in the Western Region of Nigeria, Adelabu stated to the public that Western Nigerian Government was in "a state of a peculiar mess" (Extract 6). His largely illiterate and half-educated audience were enamored by his strange and apt coinage of an epithet. They consequently nativized the pronunciation as "a state of penkelemesi". Till death and now, his popular sobriquet became Adelabu Penkelemensi. The phrase became institutionalized in Nigerian English, particularly in Yoruba, Western Nigeria. When a Nigerian or Yoruba speaker says that they are in a state of penkelemess, they mean that they are in "a very serious mess, trouble or emergency".

There was also Mbonu Ojike (1912-1959), an Eastern Nigerian orator and nationalist who urged Nigerians to "boycott the boycottables" (Extract 7) (quoted in Jowitt, 1991, p. 23). The coinage sounded big and attractive to illiterates, half educated, and even educated Nigerians (see Jowitt, 1991, p. 23). Soon, the air waves and newspapers were resonating with "boycott the boycottables". Musicians and labor activists made songs and chants of the coinage. The way the nationalists used English, beginning from Zik of Africa, who was the most popular in the habit, prepared the grounds for the use of language explosives by later generations of Nigerians.

Extract 8 was very popularly used from the 1970 s to the early 1990s in broadcast media and by teachers to assert a social reality:

\section{Extract 8:}

$$
\begin{aligned}
& \text { Ornithological specimens of identical plumage } \\
& \text { invariably conglomerate to their nearest } \\
& \text { proximity. (Aka, 1985, p. 21) }
\end{aligned}
$$

And this is meant to convey a simple message: "Likes attract likes", or "birds of the same feather flock together" (NigE), "birds of a feather flock together" (BrE). Orators and activists of the nationalist movement bequeathed the linguistic habit of blowing grammar to post-Independence nascent literate Nigerians, writers, teachers, and speakers.

\section{Products of bombast legacy in literary works}

Wole Soyinka is an outstanding product worldwide of the legacy of dense and circuitous syntax, who is not only read English and Literature courses, but also emerged one of the best world writers in English. He was also the first African to win the Nobel Literature Prize in 1986. Scholars, critics, and readers of his works agree that his style is obscure, esoteric, and laced with dense syntactic structures that either put readers off or constrain them to consult the dictionary (ir) regularly during reading (Osakwe, 1995a, 1995b). Osakwe (1995a) quoted Niyi Osundare as saying that Soyinka composes his works in the words of iron and sentences of thunder. Examples are taken from three of his popular works: The Lion and the Jewel, a play (1963); The Interpreter, a novel (1965); and The Man Died, a novel (1972). In one of the melodramatic scenes in The Lion and the Jewel, Lakunle, the protagonist, a village teacher, 
bombards Sidi, the village belle whom he is wooing, with a rain of "grammar". Sidi insists that Lakunle must pay her bride price before he can have her, his rain of loud words notwithstanding. However, Lakunle condemns the custom of bride price, among other practices, as follows:

\section{Extract 9:}

LAKUNLE: A savage custom, barbaric,
outdated, rejected, denounced, accursed,
excommunicated, archaic, degrading,
humiliating, unspeakable, redundant,
retrogressive, unpalatable...
SIDI: Is the bag empty? Why did you stop?
LAKUNLE: I own only the Shorter Companion
Dictionary, but I have found the Longer one,
you wait... (pp. 7-8)

In spite of his language explosives, Sidi insists on his paying bride price before they can relate intimately or get married, but, suddenly, Lakunle explodes again, bombarding Sidi with more linguistic bombs:

LAKUNLE: An ignoble custom, infamous, ignominious, shaming our heritage before the world...

Soyinka here satirizes, in a hilarious style, the linguistic habit of bombast, which was a characteristic of the educated elite and teachers in pre- and post-independence Nigeria.

The Interpreter also has dense and complicated language structures. The first paragraph of the novel can scare an average, and even educated, reader of English as a second language. The morphosyntactic and semantic configurations of the entire novel are dense and complex, as in sample 10 below:

\section{Extract 10}

'Metal on concrete jars my drinklobe.' This was Sagoe, grumbling as he stuck fingers in his ears against the mad screech of iron tables. Then his neck was fiercely snapped as Dehinwa leapt up and Sagoe's head dangled in the void where her lap had been. Bandele's arms never ceased to surprise. At half-span they embraced table and chairs, pushed them deep into the main wall as dancers dodged long chameleon tongues of the cloudburst and the wind leapt at them, visibly malevolent. In a moment, only the band was left. (p.1)

This opening paragraph is not reader-friendly to an average Nigerian learner. One needs patience to wade through the dense and tight morpho-syntax and semantic embedding which describes a rehearsal or play enactment scene that a sudden downpour has disrupted. Similar dense constructions permeate his other literary works; for example, The Man Died. The last example from Soyinka is short, but perhaps denser and more complex:

\section{Extract 11:}

From us the Lillywhite King Lillypuss

To you obfuscating Blesfuscoons

From us the Herrenyolk of Egg

To you Albinos of the Albumen. (Professor Johnbull (2016))

What does a learner of English as a second language make of these poetic ellipses, coinages, and literary allusions? So, Soyinka himself is guilty (and a master) of the linguistic habit that he satirizes with the character of Lakunle in The Lion and the Jewel.

Hotel de Jordan, created in the late 1960 by Jonathan Ihonde, one of Africa's best satirists and dramatists, was the largest crowd puller from the 1970 s to the 2000s. Some of its characters, such as Dr. Milo Moroe, the Marxist economist in the series, Professor J. J. Colour, the socialist democrat, Bob Allan, the gregarious journalist, and Chief Ajas, the mindless capitalist, are a delight to watch in terms of their impeccable diction and styles. While Dr. Milo Moroe is grandiloquent and dialectical, Professor Colour speaks Queen's English, transmitting his ideological explanations in simple language, as Bob Allan does. Such brief and pungent retorts as "Chief Ajas, this is unthinkable, ridiculous, preposterous, unimaginable illogic...!" (Extract 12) by Dr. Milo Moroe is unforgettable. Primary and secondary school pupils and students who watched Hotel de Jordan in the 1970s, 1980s, and 1990s (including the researcher) used to imitate these characters, especially Dr. Milo 
Moroe's English (interview with Jonathan Ihonde, creator of Hotel de Jordan, a Nigerian over eighty years old, on the 6th of August, 2019).

In a new television drama entitled Professor Johnbull (2016), a character like Dr. Milo Moroe of Hotel de Jordan, and Lakunle of The Lion and the Jewel, has reappeared in the name of "Professor Johnbull", a role taken by Kanayo O. Kanayo, one of Nigerian popular Home Video actors. Professor Johnbull satirizes members of the Nigerian intelligentsia who are fond of bombarding their listeners and readers with tough syntax and loud words in all contexts. This character bombards other characters and his audience with bombast and dense syntax. In the drama, there are other characters such as Caro, the Professor's house help (Mercy Johnson), Elizabeth, his daughter (Queen Nwokoye), and a fake D' Banj (Yomi FashLanso). Professor Johnbull, chastising Caro for the strange way in which she reads the letters of the English alphabet in the very first episode, says that her attitude is an "exhibition of primitively atavistic tendencies... and unabashed educational jingoism" (Extract 13). Then, he berates Elizabeth for not giving Caro "anthropological larynphalothrophy" (Extract 14) before engaging her as house help.

In another scene, Professor Johnbull meets an impersonated D'banj, introduced to him as the "Koko Master." Taken aback and thinking that the name is "Cocoa Master", Johnbull begins to blow grammar, criticizing the idea of bearing cocoa as a name:

\section{Extract 15:}

The Cocoa Master?... You mean somebody's name is cocoa? Cocoa belongs to the genus theobroma family, subspecies sterculioidea of the mallow family. The botanical name is theobroma cacao. How can somebody's name be cocoa? That is taxonimical anomaly. (Professor Johnbull, 2016; Editor, 2016)

The drama series is the most recent literary endeavor to recreate the habit of detonating language explosives in Nigerian English. As in literary works, so the habit is displayed in real life, as explained in section 4.3 .

\section{Present-day bombast bombardiers in Nigeria}

Many other Nigerian writers and speakers admire and write like Soyinka and the literary characters cited above. Uthman Shodipe (1996), a columnist for the Nigerian Guardian in the 1980s and 1990s, is one of them:

\section{Extract 17: A Newspaper article}

Somewhere in the fringe of hope... buried in a nightmarish anonymity, there lies a man who once shone in the full illuminating glory of academic distinction, probing the depths of scientific arcana, flung in the immense frontiers of knowledge... No more... The votary of science is hobbled. On the solitary obscurity of the hamlet of Igbesa, Professor Olusegun, a world acclaimed pharmacologist, is prostrated in a tragic imprisonment of fate. Here, there is no vestigial trace of renown. No tarnished imprints of quondam esteem... There is vulnerability of all of us in this rioting in centrifugal resolve... Adversity does not discriminate between the sturdy palisades of the mighty or the puny hovel of the weak... (Shodipe, 1996, p. 27)

With its flowing poetic prose, no doubt, Shodipe's example above is not an easy read to an average educated Nigerian. When this researcher, first read the article as a fresh university graduate, it did not make a clear meaning, as it does to him now.

Adebayo Williams, a Language and Literature professor and columnist to several print media, and Reverend Christopher Oghenebrorie Okotie, also known as Chris Okotie, a Nigerian politician, televangelist, and pastor of the Household of God Church International Ministries, are also renowned bombast bombardiers. It is often seriocomically said that one who is going to Rev. Okotie's church must take a Bible and a huge dictionary along. Okotie's words are certainly high-sounding. He would tell his congregation to "develop a supernatural propinquity stronger than earthly consanguinity with the Almighty God" (Extract 17). Criticising the Independent Electoral Commission (INEC), Okotie asserted: 
"This is the usual PDP proclivity. I have said it before that INEC was incapacitated ab initio...it is a quango, terminological deceit..." (Bosai, 2011 , p.1) (Extract 18). A reading of his controversial book The Last Outcast, as well as a visit to his "Apocalypses", his television station, show that Okotie is highly proficient in the English language and denoting language explosives.

The extract below, which is taken from a textbook is complex, dense, and windy:

\section{Extract 19:}

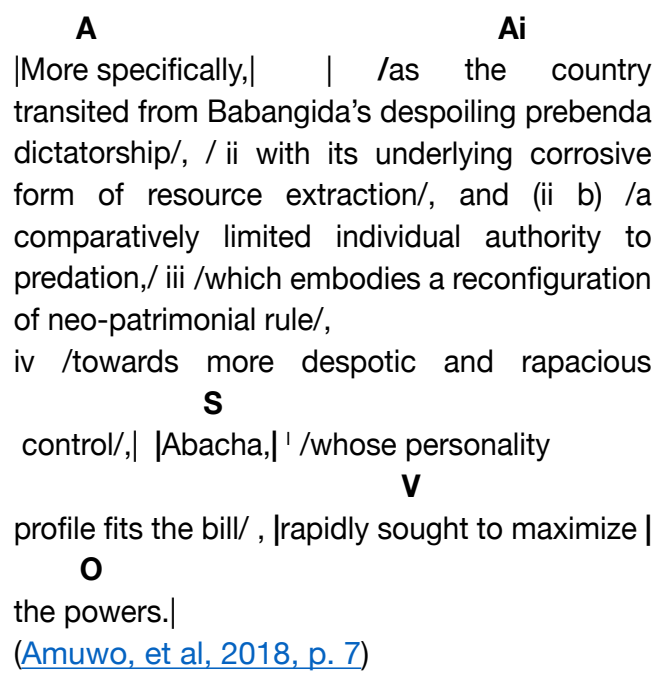

A |More specifically,| | /as the country transited from Babangida's despoiling prebenda dictatorship/, / ii with its underlying corrosive form of resource extraction/, and (ii b) /a comparatively limited individual authority to predation,/ iii /which embodies a reconfiguration of neo-patrimonial rule/, iv /towards more despotic and rapacious $\mathbf{S}$ control/,| |Abacha,|'/whose personality V profile fits the bill/ , |rapidly sought to maximize |

\section{0}

the powers.|

(Amuwo, et al, 2018, p. 7)

Extract 19 above is a complex sentence of AASVO structure, a reverse variant of SVOA (A). It has five major syntactic slots and structures. The first adverbial $\mathbf{A}$ is simple, having only two words, but the second A (adverbial) is complex, with five embedded post-modification structures, as numbered in figures, each performing a grammatical role related to the second Adverbial structure. Substructure A ii is a compound formative that postmodifies prebenda dictatorship, and A iii, postmodifies individual authority to predation in A ii b structure. Substructure A iv postmodifies the noun head of substructure iii (patrimonial head). The subject (S), consists of a simple noun head (Abacha), which the embedded relative clause attached to it postmodifies. The verb phrase is also complex, containing a simple adverb (rapidly), a finite verb (sought), and a to- infinitive (to maximise).
At present, in Nigeria, Patrick Obahiagbon, alias Igodomigodo, is the most popular bombast bombardier, along with Mr. Paul Alao, alias Fadda the Grammarian. There is also Joel Anthony, a famous blogger, and Marxist Kola Edokpayi, etc. Extract 20 is Obahiagbon's response to the question about the meaning of Igodomigodo.

\section{Extract 20:}

Igodomigodo is a political sobriquet I have habilimented to togarise my identity for a period...to emblematize my culturico-spiritual fons et origo. It was an advertent stratagem to cosmopolitanize my genealogical matrix and arcane trajectory... IGODOMIGODO, being the pristine nomenclature of the Bini man, evokes in me the alacritous presence of the invisible gods of my progenitors which, by itself, invokes a luxuriation in an ancestral egregore of pristine resurgimento. (Adebajo, 2013)

On the passing of Chief Tony Anenih, an elder statesman and political godfather, Obahiagbon (2018) clothes his condolences in complex syntax and loud words.

\section{Extract 21:}

My sincere condolences go to the family, filial and conjugal, of the late Chief Tony Anenih who has gloriously transited to empyrean ensconcement...

This gargantuan and Olympian eche homo sapien of Nostradamus vivendi will be greatly missed for constantly promoting and cascading the good people of Edo State in highly exalted positions in the Nigeria's political atmospherics...

He truly emblematized a savoir frère predilection in his political peregrination...

In Extract 22, Paul Alao Fadda, the "Egbegboya of Edo land" (who could have turned out to be a greater bombardier than Obahiagbon, but for his sudden death in 2019), a bombast bombardier in an interview, condemns in strange, deafening bombast the closure of Ladoke Akintola University of Technology (LAUTECH), jointly owned by the Osun and Oyo State Governments of Nigeria: 


\section{Extract 22:}

\section{Interviewer (Chizoba Joy Atuma):}

Hello Prof., a lot of things are going wrong with our country today, especially in the area of our institutions of higher Learning. An example is the case of Ladoke Akintola University of Technology. What do you have to say?

\section{Fadda the Grammarian:}

This impedimenta, combustible, and volatile lemma, in its maximum exoneration, reminds me of the biblical eloi-eloi lamath saba thani. Osun State and Oyo State Governors, why is this institution (LAUTECH) forsaken? What germinated the abnegation and repudiation of LAUTECH and her academic system macaronically?... Oh! What an academic muahahaha! Academic yohoho, caused by this political yoyos, political hobos, in their leadership rococo, leadership brababaration in conjunction with administrative bemusement, hoi-polloi, and discombombulation. In their obstreperous, malevolent shenanigans, and hocus-pocus agenda, Governor Ajumobi and Governor Aregbesola have discommoded and flustered 34,000 students, irreparably. Your booboo has pooh-poohed the academic pursuit of these students into yobishness...

You see, this stealing and furtive act of these rambunctious governors... political rodomontade and defatijigitators that you and I know the labanotation of their eleemosynary, ostentatious, and libidinous lifestyle shows that they are out to deplete these students of their palatable future... ...say 'no' to this babituration, dilapidation, obliteration, mutilation, decapitation, and annihilation of LAUTECH. Say 'no' to this academic bantigism, academic somnambulism, and academic malocclusion which their children are not part of.

Governor Ajumobi, Governor Aregbesola, until you ameliorate the transmogrification of this academic calendar--we will not kowtow in your powwow

\section{Reaction and attitude of Nigerians to the use of bombast}

Titus Dydimus says that "reactions to" Obahiagbon's"straight-faced comedicperformances of bombastic verbosity vary from bewilderment to amusement. You can't but ask yourself - is this guy joking or is he serious about this?" (p.1). Dydimus further reveals that many of Obahiagbon's colleagues in the Nigerian House of Representatives (2007-2011) admitted that they did not understand most of his dense and cacophonous verbiage. In the same vein, a majority of Nigerians who listen to him do not comprehend his highfalutin expressions, even though they feel entertained and admire his ability to rain bombast. Professional communicators and grammarians see his magniloquent idiolect as comic strip or stand-up comedy, a waste of words and an impediment to effective communication, which bombast often is. However, a quality we cannot take away from it is humor. Bombast sets one's audience aglow with excitement and laughter. It also makes one's audience conclude that one is well read and proficient in English, a foreign or second language, which many people fail in examination and so cannot gain admission to higher schools. For bombast bombardiers, it is a fast way of gaining popularity. Indeed, all bombast bombardiers in Nigeria are popular in their localities. People yearn for them to speak in public gatherings and feel disappointed when a highly educated speaker mounts the rostrum but fails to thrill their audience with grammar and fine turns of phrases. So, blowing grammar certainly has its pride of place in Nigeria, and it has implications for effective communication and language teaching and learning.

\section{Implications for effective communication and language teaching}

This habit is useful in certain ways and contexts in language teaching and learning, especially in second and foreign language settings. Rather than just condemning it wholesale as impeding effective communication, it could be applied sparingly in teaching vocabulary at the secondary and tertiary levels of education. Bombast bombardiers may be recommended to those who wish to develop their vocabulary in ESL, and the habit should be taught as individualized styles (idiolects) in certain dialects of language, such as ENE as a second language. Furthermore, the habit has a place in classroom pedagogy. The researcher has used it successfully for over two decades as comic relief in 
tense situations, classroom teaching, and improving learners' vocabulary and language use. In public speaking in Nigeria, the habit is a veritable way of thrilling the audience, but it should not permeate a public address from beginning to end to the extent that it ruins effective communication. Simple and effective communication should not be destroyed on the rostrum of blowing grammar.

\section{Conclusion}

This paper, which focused on the use of bombast in ENE, presented twenty-two examples from different sources, such as political discourses, oratory, literary works, standardized textbook writing, and informal interaction. It established the historical and sociolinguistic factors that entrenched bombast in ENE and further highlighted its effects on and implications for effective communication and language teaching. Furthermore, this study maintains that educated Nigerian users of language explosives are not ignorant of the communicative function of language and its symbolic status in an ESL setting, as averred in Teilanyo (2003). They deliberately set out to use bombast for a purpose. The linguistic explosives hereby examined are not necessarily errors or bad language, although their flamboyant use may be questioned at some other levels of linguistic and communication concerns. Even though bombast generates humor and could be applied for vocabulary learning in ESL, it should be used sparingly. All things considered, communication is conveying a message and sharing information, not obstructing it. In this regard, there are also many educated Nigerians who believe in plain writing and speaking, and do write and speak as simple as possible, an area that is open to further studies. It will also add to knowledge to devote further studies to account for the specific language and rhetorical strategies that (Nigerian) bombast bombardiers deploy in their oratories and writings, as well as their discourse features.

\section{References}

Adebajo, A. (2013). A compilation of Obahiagbon Staggering releases. https://adekunleadebajo. wordpress.com/tag/igodomigodo/
Adegbite, W. (2020). Sociolinguistics and the sociology of English in Nigeria. Obafemi Awolowo University Press.

Adeniran, A. (1979). Nigerian elite English as a model of Nigerian English. In E. Ubahakwe (Ed.) Varieties and functions of the English language in Nigeria (pp. 227-241). African University Press.

Aka, S. M. O. (1985). Pass English language without tears. Aka Publishers.

Akere, F. (2006). The English language in Nigeria: The sociolinguistic dynamics of decolonisation and globalisation. In W. Adegbite $\&$ B. Olajide (Eds.), Reinventing the English language in Nigeria in the context of globalisation and decolonisation (pp. 2-16). Nigerian English Studies Association

Amuwo, K., Bach, D. C., E Lebeau. Y (Eds). (2018). Nigeria during the Abacha Years 1993-1998. Institute for Research in Africa (IFRA). https://books. openedition.org/ifra/632?lang=en

Banjo, A. (1971). Towards a definition of standard Nigerian spoken English. Actes du 8e congress de la Societe Linguistique de l'Afrique Occidental. Annales de Universite d'Abidjan, (pp. 165-175). Centre for Research and Action Peace (CERAP).

Banjo, A. (1996). Making a virtue of necessity: English in Nigeria. Monsuro Publishers.

Bosai, D. (2011). Quango-terminological deceit-Pastor Chris Okotie us Patrick Obahiagbon. https://www. gistmania.com/talk/topic,60561.0.html

Didymus, T. (2012). Obahiaghon's comedy: A parody of the 'beauty of simplicity' lost in today's world. http://www.digitaljournal.com/ article/319887\#ixzz5bxrf1mwA

Editor. (2016, 24 July). Professor Johnbull wows television viewers with bombastic English. Nigerian Guardian. https://guardian.ng/art/professor-johnbull-wows-tvviewers-with-bombastic-english/

Ekundayo, B. S. (2014). Intraference in Educated Nigerian English [Doctoral dissertation, University of Benin]. University of Benin.

Ihonde, J. (Creator, Producer, Director). (1973). Hotel de Jordan: [Television home video satire series, 19732000]. Nigeria Television Authority (NTA).

Jones, K. A. B. (1965). A life of Azikiwe. Penguin.

Jowitt, D. (1991). Nigerian English usage: An introduction. Longman.

Kperogi, F. (2013). Bad grammar about grammar in Nigerian English. https:/www.farooqkperogi. com/2013/01/bad-grammar-about-grammar-innigerian.html 
Kperogi, F. (2015). Glocal English: The changing face and form of Nigerian English in a global world. Peter Lang Publishers.

Kperogi, F. (2018). Nigerian English words you won't find in any modern dictionary. Notes from Atlanta: Nig. https://www.farooqkperogi.com/2018/09/ nigerian-english-words-you-won't-find-in. html?m+1

Mazrui, A. (2019). The political sociology of the English language: An African perspective. De Gruyter.

Merriam-Webster's. (2004). Bombast. The new international Webster's comprehensive dictionary of the English language. Trident Press International.

Obahiagbon, P. (2018). The next edition news. https:// nextedition.com.ng/2018/10/30/anenih-patrickobahiagbon-delivers-fittlyelergy/

Ohia, U. (2008). Remembering K. O. Mbadiwe. http:// www.nigeriavillagesquare.com

Okotie, C. (2001). The Last Outcast. Marskeel Publishers.

Omolewa, M. (1979). The emergence of non-standard English in Nigeria 1842-1926. In E. Ubahakwe (Ed.), Varieties and functions of English in Nigeria (pp. 1426). African University Press.

Osakwe. M. (1995a). A linguistic guide to Soyinka's Idanre and other poems. University Press.

Osakwe. M. (1995b). The language of Wole Soyinka's a shuttle in the crypt. African University Press.
Professor Johnbull. (Lead Actor). (2016). Professor Johnbull. Television drama series. Nigerian Television Network (NTA International).

Quirk, R, Greenbaum, S, Leech, G, E Svartvik, J. (1985). A comprehensive grammar of the English language. Longman.

Radu, V. (2019). Recording-keeping qualitative method of research. https://www.omniconvert.com/qualitativeresearch-definition-methodology-examples.html

Schreier, A. A. Wilson, K., \& Resnik, R. (2016). Academic research record-keeping: Best practice for individuals, group leaders and institutions. Journal of the Association of American Medical Colleges 8(1), 42-47. https://doi.org/10.1097/00001888-200601000-00010

Shodipe, U. (1996, August 27). The talent destroyed. Nigerian Guardian, p. 27.

Soyinka, W. (1963). The lion and the jewel. Oxford University Press.

Soyinka, W. (1972). The man died. Spectrum Publishers.

Soyinka, W. (1975). The Interpreter. Fontana.

Teilanyo, D. I. (2003). The use of bombast in Nigeria: The examples of Icheoku and Masquerade. Africa Today, 50(1), 77-104. https://doi.org/10.1353/at.2003.0069

Ubahakwe, E. (1974). Bookish English among Nigerian students. Journal of the Nigerian English Association, 6(1), 38-51. https://doi.org/10.2478/ v10015-011-0036-7 